This article was downloaded by: [New York University]

On: 19 April 2015, At: 01:45

Publisher: Routledge

Informa Ltd Registered in England and Wales Registered Number: 1072954

Registered office: Mortimer House, 37-41 Mortimer Street, London W1T

3J H, UK

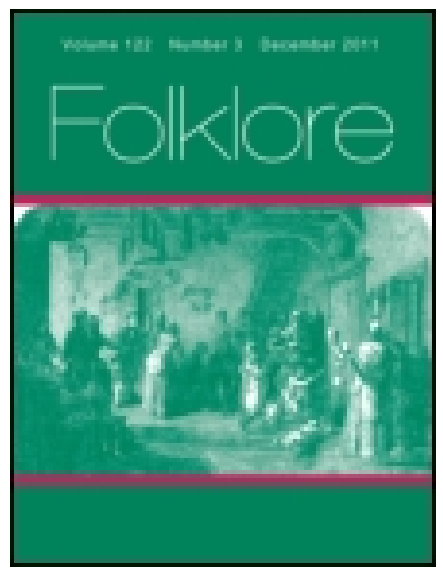

\title{
Folklore
}

Publication details, including instructions for authors and subscription information:

http:// www. tandfonline.com/loi/ rfol20

\section{Report on Greek Mythology}

\section{F. B. J evons}

Published online: 14 Feb 2012.

To cite this article: F. B. J evons (1891) Report on Greek Mythology, Folklore, 2:2, 220-241, DOI: 10.1080/ 0015587X.1891.9720059

To link to this article: http:// dx. doi. org/ 10.1080/0015587X.1891.9720059

\section{PLEASE SCROLL DOWN FOR ARTICLE}

Taylor \& Francis makes every effort to ensure the accuracy of all the information (the "Content") contained in the publications on our platform. However, Taylor \& Francis, our agents, and our licensors make no representations or warranties whatsoever as to the accuracy, completeness, or suitability for any purpose of the Content. Any opinions and views expressed in this publication are the opinions and views of the authors, and are not the views of or endorsed by Taylor \& Francis. The accuracy of the Content should not be relied upon and should be independently verified with primary sources of information. Taylor and Francis shall not be liable for any losses, actions, claims, proceedings, demands, costs, expenses, damages, and other liabilities whatsoever or howsoever caused arising directly or indirectly in connection with, in relation to or arising out of the use of the Content.

This article may be used for research, teaching, and private study purposes. Any substantial or systematic reproduction, redistribution, reselling, loan, sub-licensing, systematic supply, or distribution in any form to anyone is 
expressly forbidden. Terms $\&$ Conditions of access and use can be found at http://www.tandfonline.com/page/terms-and-conditions 


\section{REPORT ON GREEK MYTHOLOGY.}

Selene und Verwandtes von W. H. Roscher. Mit einem Anhange von N, G. Politis uber die bei den Neugriechen vorhandenen Vorstellungen vom Monde. Leipzig, Teubner.

Die griechischen Sakralaltertümer. By Dr. Paul Stengel. Being vol. iii of I. v. Müller's Handbuchder klassischen Altertumswissenschaft. München, 1890.

Dictionnaire des Antiquites Grecques et Romaines. Daremberg et Saglio. Fascicules 13 et 14 . Paris, 1890.

THAT Selene is the moon is, perhaps, one of the few things which even a mythologist with a theory would not venture to deny. It is therefore a testimony to the spread of folk-lore methods that even a treatise on the mythology of an acknowledged nature-goddess is unable nowadays to ignore the folk-lore of the subject. And the testimony is still more striking when the treatise in question is written by one of the straitest of the sect of meteorological mythologists. For of such we must consider Roscher to be, in spite of his protests. He protests that, if in his previous mythological studies he has found nothing but wind and weather myths, the reason simply is that wind and weather myths have accidentally happened to form the subject of his previous studies. Be this as it may, it is matter for much satisfaction that he tells us in the preface he has employed the comparative method, and has sought for parallels not only amongst peoples related to the Greeks, but also amongst peoples not related to them. Still more satisfactory is it to hear him express his "conviction that genuine folk-myths are for the most part much older than the writers who have accidentally transmitted 
them to us", and consequently that the genuinely antique "is very often preserved in its purest form in late, and even in the latest, authorities". It is to be regretted that Roscher has not formally stated on what principle he decides whether the version of a myth presented by a late authority is or is not primeval ; for though he sometimes acts on the right principle, he also sometimes acts on the wrong one. Indeed, it seems as though he had never faced this question of mythological method, or even realised the existence of the question. The result is that his book is valuable principally as a comprehensive collection of material from the classics. The value of his conclusions secms to me extremely uneven; but let me place some of them before the reader, in order that he may judge for himself. And I will begin by giving some instances in which Roscher has, as it scems to me, acted on the right principle-the principle that a belief, tale, rite, or custcm, however late the authority for its existence, may be regarded as primitive, provided that it can be shown to exist, or have existed, among some other savage or primitive people. The wrong principle, which I will also illustrate from Roscher, is that a belief, etc., may be regarded as primeval because it appears "simple", or because it is common in classical poetry, or because Aristotle or Galen adopted it.

Thus, the belief that the spirits of the dead take up their abode in the moon, even if the belief were mentioned as existing in Greece by no authority earlier than Plutarch, would be rightly regarded, as it is regarded by Roscher, as primitive, on the ground that some South American tribes also entertain it. Readers of FolK-LORE, remembering Mr. Frazer's demonstration (vol. i, pp. I 48 ff.) that the wisdom of Pythagoras was but the folk-lore of the peasant, will be pleased to find that Pythagoras also regarded the moon as the abode of the departed (Iamblichus, Vita Pythag., xviii, 82). Again, that the sun and moon are a pair of lovers, or a married couple, is a conception which is rightly vin- 
dicated by Roscher as primitive, with a reference to Lithuanian and Russian folk-songs, and Lettish, Teutonic, and Otaheitian sagas. So, too, the belief that the moon is an all-seeing eye is shown by Roscher to be primitive by a reference to its existence among the Germans, Egyptians, and Mongols. Finally, the belief that anything done or suffered by man on a waxing moon tends to develop, whereas anything done or suffered on a waning moon tends to diminish, is rightly claimed as primitive by Roscher on the ground that it is widely spread amongst all peoples.

On the other hand, the connection between the moon and menstruation, on which Roscher bases a good many of his inferences, cannot be regarded as primeval merely because it seems to Roscher "extremely simple and natural". To primitive man the connection may or may not seem obvious; but his notion of simplicity is not always the same as ours, and, until instances are produced of savages believing in the connection, we have no right to say that the idea is so simple and "natural" that it must be primitive. Nor does this idea of Roscher's necessarily derive support, as he imagines, from the primitive belief that pregnancy and delivery are affected by the moon. This belief can be satisfactorily explained as a case of that general sympathy between the waxing or the waning of the moon and the fortunes of man (or woman), which we noticed in the last paragraph. Again, Aristotle, Cicero, Pliny, the Stoics, and others may have imagined that dew was deposited by the moon, and that for this reason the growth of vegetation was the work of the moon; but we must refuse to accept the speculations of late philosophers as evidence of what primitive man thinks on the subject. For one thing, it is not dew that the savage prays to the moon for. He prays for what he wants. Thus the Hottentots say, or said, to the moon: "I salute you ; you are welcome. Grant us fodder for our cattle, and milk in abundance" (Kolben, Present State of the Cape of Good Hope, 1731). For another thing, the crops are frequently 
imagined to grow sympathetically with the waxing of the moon. Again, Roscher industriously collects the various epithets lavished by the classical poets on the moon; but the moon as it appears to the poet may be a different thing from the moon as it appears to a plain citizen, and is pretty certainly very different from the ideas entertained by primitive man or the ancient Greek peasant.

The above are instances in which, as it seems to me, Roscher, on insufficient or erroneous grounds, ascribes to primitive man conceptions or beliefs which are only found in later authorities. There are also other errors of method in Selene which naturally fall to be mentioned here. Thus, Roscher's demonstration that Artemis is a moon-goddess (to which he calls the reader's special attention in the preface) is effected largely by ignoring the possibility of the plurality of causes. For instance, the inference that because Artemis makes trees and plants to flourish, and the moon does the same, therefore Artemis is the moon, can only hold good as long as we overlook the possibility that other goddesses than moon-goddesses may make vegetation prosper-in other words, Artemis may be a goddess of vegetation. So, too, it does not follow that because cows are offered to Artemis as well as to the moon, or because both goddesses are represented in cow shape, therefore the moon and Artemis are identical. The reader of the Golden Bough knows that the tree-spirit appears as a bull or cow amongst primitive men; and the writer of the Golden Bough, if he adopted Roscher's method of mythologising, might with equal justice claim that Selene is a tree-spirit and not the moon at all. Again, the "sacred marriage" celebrated at Athens between the Sun and the Moon does not, when compared with the sacred marriage celebrated elsewhere in Greece between Zeus and Hera, prove that Zeus is the Sun, and Hera the Moon, any more than it proves that Helios and Selene are the Lord and the Lady of the May respectively.

Roscher concludes his researches with an appendix on 
the myth of Pan and Selene; and as he expressly refers to it in his preface as an illustration of the principle that a late authority may preserve the primitive form of a myth, it will, I hope, not be considered hypercritical if this attempt to estimate the value of Roscher's mythological methods concludes with an examination of his appendix. The myth, as preserved in the words of Philargyrius (ad Virg., Georg., iii, 391) is, " Pan cum Lunae amore flagraret, ut illi formosus videretur, niveis velleribus se circumdedit atque ita eam ad rem veneream illexit." The problem. is to explain the myth. The solution which Roscher offers, after making every inquiry into Pan's antecedentsas indeed he was bound to do, if he was to put Pan's alleged conduct in the proper light-is that "originally Pan was not a god of light or a sun-god"-as under the circumstances one might have hastily inferred-"but nothing more than a divine or supernatural type of the goatherds and shepherds of ancient Greece." He was, if

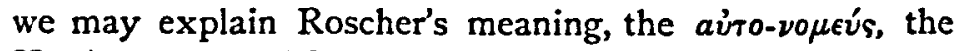
Herdsman an sich, or Herd-in-himself, living, of course, év oúpaví $\varphi$ тó $\pi \varphi$. This conception is so "simple and natural" that some of Roscher's readers perhaps will require no further proof that it is primitive. Nevertheless, Roscher proceeds to prove it. Shepherds live in caves; Theocritus and Achilles Tatius say that Pan lives in caves. Shepherds move with their flocks from place to place: "precisely the same roving life is led by Pan according to the Homeric Hymn, v. 8 ff." Many herdsmen fish, and so does Pan ("Opp. Hal. 3, 18 ; mehr b. Welcker Gr. Götterl. 2 S. 662"). Does the shepherd love his pipe? Pan loves Syrinx too (poets passim). Shepherds love to lie in the shade, and "this universal custom of the herdsmen has obviously given rise to the idea that Pan thus lies and sleeps at noon. Cf. especially Th. I, I5 ff."

Now to say that all this only shows how poets delighted to picture Pan to themselves, and that it does not show what conception their peasant contemporaries had of him, 
still less how Pan appeared to the mind's eye of their primitive ancestors, would only be to repeat what has been said above. My complaint here is that Roscher's explanation does not explain. Let us grant that $\mathrm{Pan}$ is a hunter, that the hunter sleeps out of nights, that the Moon looks down on him, or visits him, even as she visited Endymion - still the most remarkable feature in Philargyrius' myth requires explaining, that is, why did Pan wrap himself "niveis velleribus"? As for Philargyrius' explanation that it was "ut illi formosus videretur" - credat Roscherius. Or if this sounds disrespectful to Roscher-and Roscher is entitled, as the editor of the Ausfiilurliches Lexikon, to the respect and gratitude of every student of mythology-let me put it this way:-Roscher has proved many things, but he has omitted to prove that the garb in question was considered de rigueur in a wooer, by the shepherd swains of Greece and their mays. Yet it was evidently indispensable on this occasion. Without it Pan would not have worked his wicked will. In fine, it is of the essence of the myth ; and if it had been an ordinary costume for the purpose, Philargyrius would not have mentioned it, or would not have thought an explanation necessary.

And here I must mention it as one of the deficiencies of Selene, that Roscher never uses ritual to account for moon-myths. It may of course be suggested that it accidentally happens that no moon-myth can be explained from ritual. But I would venture to point to this myth of Pan and Selene. If Mannhardt and Frazer are right in regarding the "sacred marriage" of Zeus and Hera as a piece of "sympathetic magic" designed by primitive man to effect the union of two spirits of vegetation, and so to ensure the fertility of his fields and flocks ; and if, further, they are right in regarding $P a n$ as a spirit of vegetation, who appears most frequently as a goat, or in semi-goat shape; then it is obvious that the myth of Pan and Selene is a myth having its origin in ritual. Somewhere vol. II. 
in Greece a sacred marriage was celebrated between Pan, as a tree-spirit, and Selene, as a goddess influencing the growth of vegetation; and in this rite the person who represented Pan played the part in the dress appropriate to a goat-god.

That Selene did figure in Greece in a sacred marriage is proved by Proclus ad Hes., 0 . et $D ., 780$ : the Athenians united Selene and Helios in such a marriage. In Athens this "theogamy" took place at the time of the new moon, and the new moon is regarded by the folk as a good time for marrying, in many places (e.g. the Highlands, Kirkmichael, Statistical Account of Scotland, xii, 457). Again, that such ceremonies took a dramatic form in Greece appears from Euseb., Praep. Ev., iii, xii, 3, where it is stated that in the mysteries at Eleusis one celebrant got into the image of Helios and another into that of Selene.

If the myth of Pan and Selene may be explained from ritual, then the myths of two moon-heroines, Europa and Pasiphaë, may be explained in the same way. The kernel of both myths is the union of the moon-spirit (in human shape) with a bull. Both myths, then, have to do with a sacred marriage; the only question is, what spirit was represented in the rite as a bull? On the one hand we know both that Selene was united at Athens to Helios, and that the victim offered to (and therefore representative of) Helios was a bull. On the other hand, Selene marries Pan, a spirit of vegetation; and such spirits frequently manifest themselves as bull, cow, or ox. Of course, if Zeus turns out to be the spirit of the oak-tree, as Mr. Frazer wishes, the question would be settled as regards Europa. Meanwhile, it 'seems. probable that the sacred marriage was in both cases between the Moon-spirit and the Sunspirit. Perhaps I may add that the Moon-spirit not unfrequently appeared to primitive man in the shape of a cow, and the Sun-spirit in human shape. The sacred marriages in which both spirits were human, or both oxen, 
have naturally given rise to no myths, whereas the ritual in the case of Europa and Pasiphaë required explanation.

Since Roscher has resolutely declined to seek the explanation of any piece of Greek moon-lore in primitive ritual, just as he has refused to refer to the possibility that Artemis, Hera, and Pan may be spirits of vegetation, it is perhaps allowable to point out that ritual may possibly afford the explanation of that practice of drawing down the moon which appears in both modern and ancient Greek folk-lore. Indeed, it is as certain as things of this kind can be that on the occasion of a sacred marriage the Moon-spirit must have been conjured into the cow which represented the goddess; and it is not improbable that this way of bringing down the Moon survives in later folk-lore as a piece of witchcraft (cf. Lucian, Philops., I4).

But if this were all the evidence, there would be nothing more than a presumption in favour of the supposition. The presumption, however, may be strengthened. To begin with, there is a difference between bringing down the moon for the purpose of a sacred marriage, and bringing her down as a piece of witchcraft. In the former case the object is to ensure fertility to field and flock; in the latter usually to gain information not otherwise to be obtained. Now in folk-tales spirits may be caught, as the sea-spirit, Proteus, was caught by Menelaus, in order that questions may be answered by them ; and the moon-spirit may have been caught by primitive man for the same purpose. The question is, whether primitive man did as a matter of fact (and not merely in tales) bring the moon-spirit down to earth and obtain information from him. It is possible, fortunately, to show that he did. Strabo (503) tells us that the Albanians of the Caucasus worshipped Selene above all other gods. The priest of her temple was the most honourable man in the country next to the king, and was ruler both over the land dedicated to the templc, which was extensive and populous, and over the sacred slaves, who at times became possessed, and who frequently pro- 
phesied. When any of them was so far possessed as to wander in the woods alone, the priest, if he could catch him and fasten him with a certain sacred chain, entertained him luxuriously for a year; and at the end of the year he was offered as a sacrifice to the goddess along with other victims; and prognostications were drawn from his corpse. It is plain that here we have an instance of "killing the god", which is parallel to those given in chapter iii of The Golden Bough. The moon-spirit resided in the human victim, in the same way as she was conveyed into the cow at a sacred marriage; and part at least of the purpose with which she was conjured into the human victim was in order that she might afford information not otherwise to be obtained. Doubtless part of the purpose was also to ensure the safe and continued existence of a spirit so important as the Moon.

When once the practice of bringing down the moon had become familiar to the primitive Greek, who saw it done at sacred marriages and other rites, he was provided with an explanation of lunar eclipses: some other fellow was bringing down the moon for his private ends. And at the present day in Greece the proper way to stop a lunar eclipse is to call out, "I see you!" and thus make the worker of this deed of darkness desist. So completely did this theory of eclipses, which we must regard as peculiarly Greek, establish itself in ancient Greece, that, strange to say, not a trace of the earlier primitive theory, according to which some monster swallows the eclipsed moon, is to be found in classical Greek literature, unless the beating of metal instruments to frighten away the monster (Theoc., $\mathrm{ii}, 36$ ) be a survival of primitive practice.

One more survival from primitive ritual: Roscher quotes, but makes no attempt to explain, Pollux, vi, 76 , where it is stated that cakes called "moons", from their shape, were offered to Selene. In China, cakes on which is stamped the image of the moon, or which sometimes are circular, in imitation of the shape of the moon, play a part in the 
festival known as "congratulating" or "rewarding" the moon (M. Huc, Travels in Tartary, etc., i, 6I, and J. Doolittle, Social Life of the Chinese, ii, 65). In Lancashire "there exists a precisely similar custom of making cakes in honour of the Queen of Heaven" (Dennys, Folk-lore of China, p. 28). Jeremiah, vii, I8, says, "The women knead dough, to make cakes to the Qucen of Heaven." Plainly these are all survivals of the primitive rite of "eating the god". Fertility was thereby secured in this case. In modern Greek folk-lore a "magic cake" is used as a bait wherewith to catch the moon.

Finally, there remains the savage theory which is implied in the terms $\sigma \in \lambda \eta \nu l a \zeta^{\prime} \mu \varepsilon \nu o l, ~ l u n a t i c i$, moon-struck. Roscher's view is that the moon influences menstruation, as Aristotle holds; that irregular menstruation produces diseases, as Galen hath it; and therefore all diseases, including epilepsy, are ascribed to the influence of the moon. But primitive man did not read Aristotle, or even Galen. We want some less recondite explanation. One thing is certain: the connection between the moon and disease was something that to primitive man was self-evident. It is recognised in Brazil (Brinton, Myths of the New World, 134) as well as in Denmark (J. T. Bunce, Fairy Tales, 131), in Mexico (Brinton, 132) as well as in Iceland (Jón Arnason, Legends of Iceland, 635). Another thing we know, that is that diseases are regarded by primitive man as the work of spirits entering into possession of the sick person. And we have already seen that the moon is held by primitive folk, including Pythagoras, to be the abode of departed spirits. Is not this the connecting link? Do not the spirits dart straight from the moon into any person who is not on his guard against them, or is for any special reason an easy prey for them? According to Porphyr., De Antro Ny., 28, 29, "theologians" say the sun and the moon are the gates by which departed souls pass from and to the earth; and the moon is the gate by which they come down to the earth. In Iceland, "if a pregnant 
woman sits with her face turned towards the moon, her child will be a lunatic" (Arnason, supra). "The Brazilian mother carefully shielded her infant from the lunar rays, believing that they would produce sickness" (Brinton, supra). In Greece, "nurses take every precaution to avoid exposing infants to the moon" (Plutarch, $Q$. Conv., III, $\mathrm{x}$, 3). And it is hardly necessary to remark that new-born children and puerperæ are alike tabu, and particularly liable to possession (as regards classical antiquity, cf. Suid., $\dot{a} \mu \phi i \delta \rho o ́ p c a$, and Censorin., $D e$ die nat., c. 11,7, p. 28, Jahn).

Dr. Stengel's book on the Ritual Antiquities of Greece is part of Iwan von Müller's valuable series of manuals of classical antiquities. IVe may, perhaps, not unreasonably regard it as a sign of the times worth noting in FolkLORE that the German school-boy will be henceforward taught that the Greek religion was no "nature-religion", that the attempt to identify Greek gods with naturepowers or natural phenomena is a failure. $\mathrm{He}$ is further to be taught that similarity between the myths of different nations does not necessarily imply borrowing, or even joint inheritance from the beliefs of common ancestors: it presumably points only to similarity in the mental constitution of different peoples. And, further, the capacity to believe in the actual, visible, and tangible appearance of supernatural beings was not confined to pre-historic times, but lived ever fresh and flourishing right throughout historic times. All this is most excellent. But it is quite as necessary in folk-lore as in politics "to be always asking. for cverything you can think of, to be always taking all you can get, and be always grumbling about what you have not got." Then come, let us grumble.

In the first place it is strange that, in a work dealing with ritual from the point of view just described, there is no recognition of the fact that, amongst the things which myths are invented to explain, are rites themselves. And this is the more surprising because the Dionysia are 
admitted in Roscher's Lexikon to be the source of some of the Dionysos myths. In the next place, although we may admit that in a manual there is not room for illustrations from the rites and beliefs of non-classical peoples, and that Dr. Stengel has only to do with Greek ritual, as he pleads (p. 97); still, we must protest that it is impossible to construct a sound account of even Greek ritual without a previous scaffolding of non-Greek material. For instance, though the Greeks may have borrowed the notion of "sin" and "sin-offerings" from Semitic sources, no one who is aware how widespread, indeed universal, is the belief in the possibility of transferring sickness and other ills (from warts upwards) from the sufferer to animate or inanimate objects, will admit that the notion of the "scape-goat" was at any time foreign to the Greek mind. The absence of any reference to this mode of purification in Homer can scarcely be regarded as conclusive. And this brings us to a third grumble-on a question of method. Dr. Stengel begins by laying down the statement that, in the matter of myths and gods, foreign influence is only to be detected in post-Homeric times, and for several centuries after the Homeric age it was extremely small. This, taken as a statement of results, is, perhaps, somewhat too sweeping ; but regarded as the expression of a resolve to admit borrowing to have taken place only where and when intercourse between the people borrowing and the people lending can be demonstrated to have existed on satisfactory grounds, it is a laudable position to take up. It is the method of carrying out this praiseworthy resolve that is open to protest. Thus, Dr. Stengel is apparently satisfied that purification (and also human sacrifice) must have been borrowed by the Greeks from the East. Neither rite is mentioned in Homer. Intercourse between Greece and the East was constant and active in post-Homeric times. Therefore the rites were borrowed in historic times. The whole issue, then, turns on the question whether it is justifiable to assume that a rite did not 
exist in Homeric times because it is not mentioned in Homer. This is a question of the same nature as whether we are justified in assuming that a myth or a folk-tale did not exist at a time earlier than its first recorded mention in literature; and the answer seems to be the same. If the rite or myth can be shown to be one common amongst primitive peoples, the argument $e$ silentio has little weight; and as regards human sacrifice and purification, $\mathrm{Mr}$. Frazer has amply proved that they are primitive. There is no more reason to imagine that the Greeks borrowed them from the East, whether in pre- or post-Homeric times, than that the East borrowed them from the Greeks.

As I have spoken of Dr. Stengel's book as one for school-boys, I ought, perhaps, to add that it is also intended for university students, and anyhow that it is a very valuable collection of facts and references, which folklorists will find useful. Those interested in tabu and totemism will note that the priest of Poseidon at Megara and the priestess of Hera in Argos were forbidden to eat fish. They will also note that the priestess of Athena Polias at Athens was forbidden to eat the native cheese. Finally, Dr. Stengel's treatment of Mysteries is rather disappointing. $\mathrm{He}$ is, doubtless, quite right in saying that the hold which they took over the minds of the Greeks was due to the fact that they taught the doctrine of a future life; and it is not improbable that the scenic representations which took place were dramatisations of myths whose central feature was the resurrection of some god. But it is also probable that some of the central rites round which this teaching gathered were survivals from savage ritual. One such rite at Eleusis is that in which Helios and Selene figured (Eusebius, $l . c$ ), whether the interpretation be that which I suggested above or not.

If we may take Daremberg and Saglio's magnificent Dictionary of Classical Antiquities as fairly representative of the attitude of classical scholars in France, there is no 
country in Europe in which folk-lore methods have made so little impression on students of classical antiquities. In the two numbers of the dictionary last issued there are three articles of importance to folk-lorists: Dionysia, Dioscuri, and Divinatio. MI. Reinach, the writer of the article Dioscuri, is indeed not ignorant of what has been done from the side of folk-lore on his subject. He can even quote, from La Mythologie par Andrew Lang, parallels to the Dioscuri amongst the aboriginal Australians and the Bushmen. But, alas! he only quotes them as curiosities. With the article Divinatio, which is a marvellously comprehensive collection of material, things are still worse. The numerous survivals still extant of primitive methods of forecasting the future are not quoted even a titre de curiosite. And, what is worse, the writer deliberately declines to consider parallels from other nations than the Greeks, Romans, and Etruscans, on the ground that so much are all nations alike in these beliefs that study of other peoples would probably only add a multitude of facts similar to those already known to the classical students, but would not open up any new points of view!

Consistently enough, M. Bouché-Leclerq's method is purely a priori: grant him a couple of propositions which are self-evident to educated man of the nineteenth century, and he will deduce from them the faith in divination in all its branches. And yet if there is a thing which civilised educated man can not do, it is to say $\dot{a}$ prior $i$ how things will strike the savage mind. For illustration we need go no further than M. Bouche-Leclerq's fundamental assumptions, viz., that all we require to assume in order to believe in divination is that the gods are able to communicate information, and that being able they are willing. But M. Bouché-Leclerq has at the very beginning overlooked a contingency which is not unknown in savage experience, however unlikely to occur $\grave{a}$ priori to a modern savant: the gods may not be willing. In 
that case they have to be made to tell; and primitive man wrestles (in the case of Proteus literally) with them. Thus, the modern savant's two assumptions may be reduced to one, viz., that the gods are able to communicate information; and is not that superfluous? In many or most of the methods of divination common in modern folk-lore there is no suggestion that the desired information is obtained from supernatural beings. Nor is it relevant to rejoin that the modern methods are survivals from modes which were in the first instance interrogations addressed to supernatural beings. Be this true or not, the fact remains that the folk believes in the possibility of divining the future without supernatural aid. You can tell from the state of the moon what the weather is going to be, and you can also tell of what sex your next child will be. But the many educated persons who still divine changes in the weather, and the uneducated few who practise the other form of divination, are both innocent of any attempt to obtain their information from supernatural beings. In fine, primitive man has other modes than the supernatural of forecasting coming events, just as much as scientific man; and if there ever was a stage in human evolution when man had not yet attained to the idea of the supernatural, divination may well have been practised in that stage. Doubtless, the inference that beings who are supernatural have knowledge of the future is a conclusion which naturally follows from the premises. But we do not find that all the gods in the same pantheon have alike the power of prophecy; and if some gods have it not, it is evidently not a necessary attribute of supernatural beings. In this connection it may be interesting to point out that even Apollo did not always forecast the future by the exercise of an inherent power of supernatural foresight. Like Pythagoras, he (or the workers of his oracle) put his faith in folk-lore. At any rate, this is the inference which I draw from the answer given by the god of Delphi (and preserved in Euseb., 
Praep. Ev., vI, i, 2) to a person inquiring what sex his next child would be. The oracle is indeed somerrhat obscure; but when illustrated by the folk-lore recorded in F. L. J., v, p. 208, and vi, 9I, it may be seen to be based on the belief that if a birth takes place on the growing of the moon, the next child will be of the same sex; if on a waning moon, not.

In fine, it is impossible to divide primitive modes of forecasting the future into supernatural and non-supernatural, and confine the term "divination" to the former class. There is scarcely a member of either class which may not pass over into the other class. What may have been supernatural in its origin, survives as something not supernatural. What was in its origin possibly illogical but certainly not supernatural, comes to be explained as supernatural in ages when belief in this mode of communication between man and god is orthodox, as, for instance, in the time of the Stoics. This method of classification, then, confounds together things which have their origin in very different tendencies of the human mind. At the same time it obscures the relation of divination to "sympathetic magic", both of which are based on the belief that if one of two similar (or related) things is affected in any way, the other will be affected in a similar way. This belief when employed in Observation results in divination; when employed in Experiment, results in what may be conveniently called sympathetic magic, though there is not necessarily or originally anything supernatural about it. It is a mere matter of logicsavage, perhaps, rather than scientific, but still of logic, not of superstition-that if one member of a pair of similar or related things is in your power, you can affect the other as you wish; and that if one member is within the range of your observation you can tell how the other is faring. Thus, a lock of hair places the person from whose head it is cut (and to whom it is related, according to the primitive interpretation of the category of Relation) in 
the power of the person into whose hands it is given. Thus in the Alcestis, Death draws his sword to cut off a tress of the hair of Alcestis,

"for sacred to us gods below,

That head whose hair this sword shall sanctify."

And amongst modern Greeks at a christening, "three tiny locks of hair, if these can be found, are cut from the baby's head and thrown into the font, ' in the name of the Father, Son, and Holy Ghost'" (Miss Garnett, The Women of Turkey, p. 73). So, too, in folk-tales, a portion of the hero's apparel, etc., serves to inform him or her with whom it is left whether the hero is or is not still alive. May not the custom of preserving locks of hair in ockets, etc., have had its origin in some belief of this kind?

Be this as it may, in dealing with divination the important thing is to remember that in the definition of it as "supernatural communication" we have a theory embodied. That theory is one originated by the Stoics ; and conformable as it may have been to the knowledge of the age in which it was formulated, it does not satisfy the requirements of scientific folk-lore. When some Mill of the future comes to write the "Principles of Savage Logic", it will be clear to all that many modes of divination and much magic are but methods of observation and experiment which in one age were, and in a subsequent age were not, considered valid by logicians. It will be also clear that there is not that absolute hiatus between savage and scientific logic which is generally assumed. On the contrary, the Law of Continuity holds here as elsewhere. The difference between the two logics is not, for instance, that the Methods of Agreement and Difference are known to the one and not known to the other; nor even that the savage imagines points of likeness or difference where they do not exist; but that savage and scientific man differ as to what points of similarity or dissimilarity 
are essential-and not even Mill professes to lay down rules for distinguishing the essential from the non-essential features of the phenomena to be investigated. The difference between scientific and primitive procedure is in this case entirely extra-logical. Again, the Method of Concomitant Variations is, as we have seen, the basis of much divination and magic ; and here again the difference between the two logics is largely extra-logical. Related or similar things vary together; but what things are related or similar? The similarity which the primitive logician detects between the variations of the apparent size of the moon on the one hand, and of the actual size of sub-lunar growing or decaying objects on the other, is not regarded as essential by the man of science; and, speaking generally, we may say that is impossible to say $a$ priori what points of similarity or dissimilarity primitive man will seize on as cardinal. And this amounts to saying that a complete history of logic from primitive times can only be written by the aid of folk-lore.

Hypothesis is another instrument of thought which is common to both stages of logic, and which is of interest to the folk-lorist. Indeed, if we accept the definition of folklore given in $F .-L . J$., iv, p. 196, that it is "the popular explanation of observed facts", then Hypothesis is the whole of folk-lore. But even if we limit ourselves to the statement that all popular explanations of observed facts are folk-lore (and this has the advantage of not excluding rites and customs), the importance of Hypothesis is still considerable. And here, again, the difference between savage and scientific man is not so considerable: both may accept Mill's definition that " an hypothesis is any supposition which we make in order to endeavour to deduce from it conclusions in accordance with facts which are known to be real". The principal difference lies in a difference of opinion as to the nature and necessity of verification; and with regard to primitive hypothesis as preserved in myths, we may say that it consists in explaining the thing that is 
by the thing that is not. The bearing of these remarks may be seen in their application to some of the myths quoted in the article Dionysia, in Daremberg and Saglio. The writer of the article, M. Jules Girard, rightly follows Roscher's Lexikon in various points, but unfortunately does not follow the Lexikon in adopting Mannhardt's explanation of the orgiastic elements in the worship of Dionysos. Again, he is unfortunate in following the Lexikon in deriving the orgiastic elements from Thrace, and dating their spread in the time after Homer. I say unfortunate for two reasons; first, because while accepting the Lexikon's view, he apparently unconsciously rejects the evidence on which alone it is based ; and, second, because the view is, as I will proceed to suggest, itself unsatisfactory. If Mannhardt's explanation (Wald-und Feldkulte, i, 534 f.) is correct, then the mad dances and shouts, which are the orgiastic elements, date from at least Aryan times, and must have been known to the Greeks not only before the time of Homer, but before the Greeks appeared in Greece. They are primitive man's way of wakening the spirit of vegetation from its winter slumber. There can have been no borrowing by one Greek tribe from another ; each Greek tribe brought this piece of primitive magic along with it. What, then, is the evidence for the assertion that these orgiastic rites were borrowed from Thrace? It is, first, that they were not known to Homer (or as Lobeck, Aglaoph., 288, more cautiousiy says, were at the most known to the Greeks only by rumour); next, that the worship of Dionysos has every mark of having existed from the hoariest antiquity amongst the Thracians; and, third, certain legends or myths about the introduction of the mad rites into certain places in Greece. With regard to the first item, there is a passage in Homer (Il., vi, $132 \mathrm{ff}$.) which all admit to refer to the orgiastic worship of Dionysos, but not ali admit to be genuine. Now, we may either reject this passage, with F. A. Voigt, the writer in the Lexikon; or retain it, with M. Girard. But it does 
not seem admissible to do as M. Girard does, and accept Voigt's conclusion while disagreeing with his premises. In other words, if the orgiastic rites existed in Homeric Greece, the second piece of evidence given above loses its value: the inference, that the Greeks borrowed the rites from the Thracians, has some cogency only so long as we believe that the latter were earlier in possession of the rites than the former. There remain the myths alluded to. These agree amongst themselves in representing the god as punishing those who resisted the introduction of his orgies, and they are regarded as "evidently reminiscences of opposition offered to the introduction of a new and foreign worship". But to find reminiscences of historical fact in myths is to extract gold from the sunbeams. If myths are folk-lore, and folk-lore is primitive hypothesis, the one thing certain is that the assumed historical occurrence which the "popular explanation" uses to account for its "observed facts" is not historical at all. Whatever the etymology of "Shotover" Hill, it was never shot over by Little John; nor does this primitive hypothesis contain a reminiscence of any historical fact. The one thing we can infer with certainty is that the original name of the hill was near enough for the folk to confound it with the words "shot over". So, too, the one thing we can be certain of in these myths is that they were designed to explain the orgies. Why did the women of Eleuthera, a village at the foot of Cithæron, dance in this mad way at the Dionysia? Because Dionysos sends the madness on them. What! on his worshippers? Ah! but they were not always worshippers of his: once Dionysos appeared in a black goat-skin to the daughters of Eleuther, and they derided him; so he sent his madness on them, and did not withdraw it until their father, after consulting Apollo, adopted the cult of Dionysos of the Black Goat-

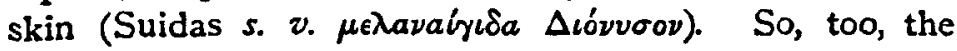
daughters of Protus of Tiryns were driven mad by the god because they refused to enter into his orgiastic rites 
(Apollod., II, ii, 2). In the Eleuthera myth it is Dionysos who himself introduces his own worship, sends the madness, and cures it. In the Tiryns myth, Dionysos sends the madness and Melampus, the seer, cures it. But inasmuch as Herodotus $(\mathrm{ii}, 49)$ says that Melampus introduced the worship of Dionysos into Greece, and in view of the resemblance between the names Melampus and Melanaigis, is it fanciful to suggest that "Black-foot" was an epithet of the god in Argos, just as "Black-skin" was at Eleuthera? Leaving this suggestion for what it is worth, let us turn to the most famous of this class of myths, that of Lycurgus, the son of Dryas, who chased the nurses of frenzied Dionysos, and smote them with the murderous pole-axe, while Dionysos fled trembling to Thetis for refuge in the sea (Il., vi, 142). Here it is not the women of Thrace, but the king who resists the god. The king, however, is punished with madness because of his resistance (Apollod., III, $v, i$.), like the daughters of Eleuthera and the women of Argos; and we might not unreasonably class all three myths together as primitive hypotheses of the same kind. But the mention of the pole-axe, and the retreat of Dionysos, may point to an instance of "killing the god". The god may have appeared as a bull in this rite, in the same way that he did at Bouphonia-hence the Bovm $\lambda \eta^{\prime} \xi$. The Bouphonia, according to the story, was instituted in order to put an end to drought and famine, and is therefore probably a harvest festival (Golden Bough, ii, 41). Drought and famine also play a part in the story of Lycurgus (Apoll., l. c.); and we may perhaps regard this myth as the "popular explanation" of a harvest festival in which the god of vegetation was killed. Originally the god was killed "only as a necessary step to his revival or resurrection in a better form". But when this was forgotten, the killing required explanation. An enemy alone would kill the god, and he must have killed him because he objected to his mad rites. He must, therefore, have been some one having authority-a king. But the god 
was unlikely to let his enemy go unpunished; therefore he sent drought and famine, as a god of vegetation naturally might. And in commemoration of the termination of the drought, which ended when Lycurgus had been torn in pieces by horses, this very harvest festival was instituted. This may or may not be the explanation of the Lycurgus myth; but it is more in accordance with folk-lore methods than the "reminiscence" theory. Anyhow, the upholders of the theory that the worship of Dionysos was borrowed by the Greeks from Thrace, ought not to cite Lycurgus in their support; for if his myth is a "reminiscence of opposition offered to the introduction of a new foreign worship", then, as Lycurgus was a Thracian king, the new and foreign worship did not originate in Thrace.

F. B. JEVONS. 